\title{
Assessment of the Impacts of Electricity Subsidies in Sri Lanka
}

\author{
W.D.A.S. Wijayapala and T.N. Kankanamge
}

\begin{abstract}
The government of Sri Lanka has been providing over decades, subsidies on electricity to uplift the living conditions of Sri Lankans. This research project scrutinizes whether the objectives of providing electricity subsidies have been fulfilled. Furthermore, both positive and negative impacts of the electricity subsidy are descriptively discussed. Appropriate remedial actions are proposed to lessen the effects of indirect negative impacts that are identified. Through the analysis, it was found that some of the primary objectives of the electricity subsidy have not been achieved. One of the most subtle negative impacts of the electricity subsidy is the encouragement it provides to subsidized consumers to use energy inefficient equipment. A case study was conducted in Ratnapura district to investigate the energy inefficient equipment usage and to quantify the resulting electricity wastage. The findings of the study were used to estimate the amount of electricity wasted in the entire country through the use of inefficient equipment. Furthermore, it was found that the existing tariff structure encourages energy inefficient equipment usage and that it therefore acts in contradiction to the fundamentals. The replacement of incandescent lamps by energy efficient equipment is analyzed as a means of saving electricity and meeting the demand during peak times in the night, and resulting savings estimated. Moreover, the investment on replacing incandescent lamps by energy efficient equipment is estimated and its financial returns evaluated.

It is also revealed that there are many loopholes in the criteria used for selecting consumers for receiving the subsidy. The major shortcoming is that it allows unwanted people to enjoy the subsidy. It is seen that modifications are needed for the electricity subsidy eligibility criteria to ensure that only needy people receive the subsidy.
\end{abstract}

Keywords: Subsidy, Energy inefficiency, Peak electricity demand, Conservation

\section{Introduction}

A subsidy is simply identified as assistance provided to a product, service, economic sector or business. A subsidy may include direct grants, tax reductions or exemptions. Furthermore, it controls prices and indirect regulations that skew the market in favour of a particular commodity. Most subsidies are introduced by governments to achieve certain outcomes. Subsidies are one of the powerful policy tools in the hands of a government that can be used to rectify economic, social and environmental impacts. In many countries, subsidies are used to achieve a wide range of objectives. Indeed one of the most challenging responsibilities of a government is the allocation of sufficient amounts of financial resources for subsidies. A subsidy may achieve its intended objectives effectively but

it may also have a few negative and unintended consequences such as corruption, inefficiency and environmental degradation. There should be continuous monitoring and fine tuning to minimize these indirect negative impacts. Economically, some subsidies can have a direct impact on the price and demand of the goods or services concerned since subsidies include government grants, tax reductions or exemptions from price control.

It is said hypothetically that social welfare is rich when the price of each good or service is freely determined by the interaction of demand and supply in open and competitive markets. This ideal situation is hardly achieved in practice in small and restricted economies and therefore interventions by governments are often required to maintain social justice. Like so many other developing countries in the region, Sri Lanka also provides a variety of subsidies. Energy, agriculture, petroleum, education and health sectors in Sri Lanka are the key sectors which are supported by subsidies. These subsidies have made tremendous impacts during the past several decades on the life styles of the Sri Lankans.

Eng. W.D.A.S. Wijayapala, Int.PEng(SL), C.Eng,
FIE(Sri Lanka), B.Sc. Eng (Hons) (Moratuwa),
MEng(Moratuwa), Senior Lecturer, Department of
Electrical Engineering, University of Moratuwa.
Email:anurawijayapala@yahoo.com
Eng. T.N. Kankanamge, C.Eng, MIE(Sri Lanka), B.Sc
Eng (Hons) (Moratuwa), Electrical Engineer, Ceylon
Electricity Board. Email:navodanak@yahoo.com


The focus of this research is to assess whether the original intentions of the electricity subsidy provided in Sri Lanka have succeeded. The study further evaluates the positive and negative impacts of the electricity subsidy and makes recommendations on the future course of action required to ensure optimum results.

\section{Electricity Sector in Sri Lanka}

The Department of Electrical Undertakings was established in 1926 by the government for electricity generation and transmission in Sri Lanka. The Ceylon Electricity Board (CEB) was later established in 1969 by an act of parliament to be responsible for the generation, transmission and distribution of electricity in the country. Later in 1983, the government established the Lanka Electricity Company Limited (LECO) to undertake electricity distribution in the outer suburbs of Colombo and in selected areas in the western and southern parts of the country. The Electricity Act of 2009 paved the way for the effective regulation of the sector by the Public Utilities Commission of Sri Lanka (PUCSL).

At present, the CEB and independent power producers are involved in the generation of electricity. While the CEB is the main system operator of the country, the power generated by the independent power producers is also procured by the CEB under purchase agreements. Hydro power plants and coal power plants are the major contributors to electricity generation in Sri Lanka. Small hydro, wind other Non-Conventional Renewable Energy (NCRE) power plants also contribute to the electricity generation. Thermal power contribution to the national electricity supply has been higher than that of hydro power. Thermal electricity generation consumes considerable amounts of fuel. The hydro-thermal mix of the past couple of years is illustrated in Figure 1. The actual generation cost of an electricity unit is dependent on the dispatch pattern of the existing power plants.

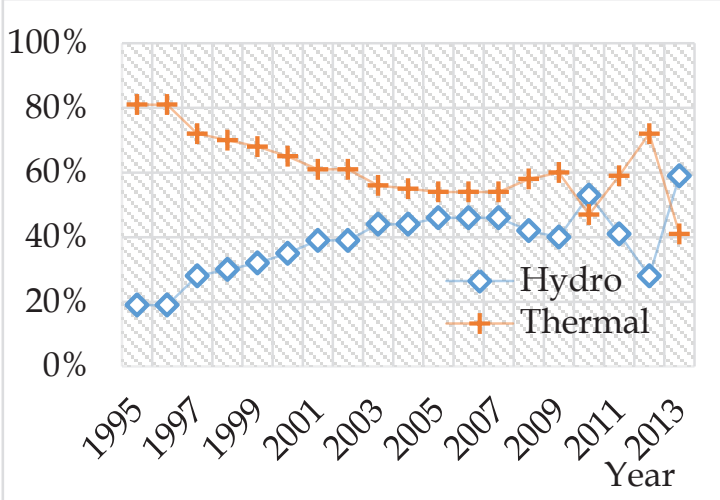

Figure 1 - Hydro-thermal mix of electricity generation [5], [6].

During dry seasons, more thermal power plants are dispatched due to the shortage of water in hydro power reservoirs. Sometimes the thermal power contribution to the total amount of power generated is as much as $75 \%$. However, the annual average electricity unit cost is calculated considering the generation expenses and associated overhead costs of the $\mathrm{CEB}$ and the cost of losses. Figure 2 shows the average generation cost and the average selling price during the period from 2008 to 2013.

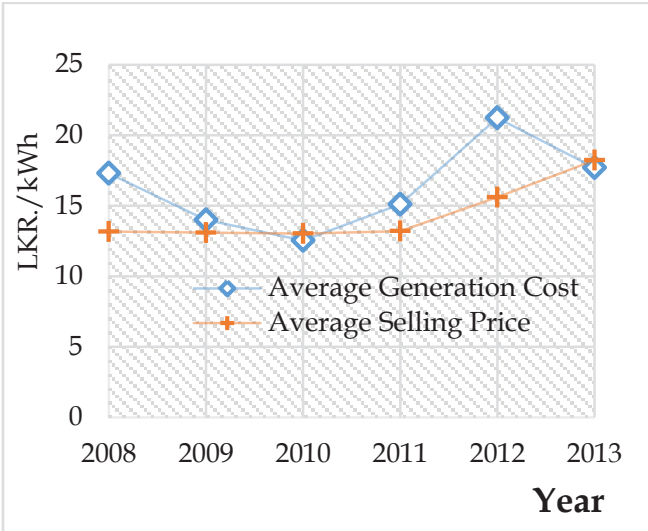

Figure 2 - Average generation cost and average selling price of electricity in Sri Lanka [5], [6].

In Sri Lanka, a block tariff structure with a block size of $30 \mathrm{kWh}$ is applied to domestic electricity consumers. The distribution of electricity consumed by these consumers under each tariff block is given in Table 1.

It is clear that almost $90 \%$ of consumers use less than $120 \mathrm{kWh}$ per month and that $75 \%$ of consumers use less than $90 \mathrm{kWh}$ per month. Consumers in the upper blocks are not entitled to the electricity subsidy. It is clear that consumers who are using over $120 \mathrm{kWh}$ per month have to pay an amount that far exceeds the average cost of a unit. 
Table 1 - Domestic electricity consumers in Sri Lanka

\begin{tabular}{|l|c|c|}
\hline \multicolumn{1}{|c|}{ Block } & $\begin{array}{c}\text { Number of } \\
\text { Consumers }\end{array}$ & $\begin{array}{c}\text { Consumer } \\
\text { Percentage in } \\
\text { Blocks }\end{array}$ \\
\hline $30<=$ Units 30 & 818,374 & $19.7 \%$ \\
\hline $30<$ Units $<=60$ & $1,257,004$ & $30.2 \%$ \\
\hline $60<$ Units $<=90$ & $1,136,860$ & $27.3 \%$ \\
\hline $90<$ Units $<=120$ & 512,048 & $12.3 \%$ \\
\hline $120<$ Units $<=150$ & 217,271 & $5.2 \%$ \\
\hline $150<$ Units $<=180$ & 98,819 & $2.4 \%$ \\
\hline Units $<180$ & 117,134 & $2.8 \%$ \\
\hline Total & $\mathbf{4 , 1 5 7 , 5 1 0}$ & $\mathbf{1 0 0} \%$ \\
\hline
\end{tabular}

Among South Asian countries, Sri Lanka is the country that has the most expensive electricity tariff for consumers using more than 90 units per month (Figure 3) [9].

Bangladesh has the lowest domestic electricity tariff rates. India has the highest rate for the industrial consumer category, while Sri Lanka has a slightly subsidised industrial tariff rate.

The government of Sri Lanka encourages rural electrification projects all over the country to make electricity available to all the households within a maximum distance of $50 \mathrm{~m}$ from the national grid.

Government's policy of gradually increasing the budgetary allocations provided for rural electrification programs has ensured that most of the rural households in the country have access to electricity. It is well reflected in the annual electrification level growth and the consumer growth shown in Figure 4.
Domestic Electricity Tariff Rates in South Asian Countries

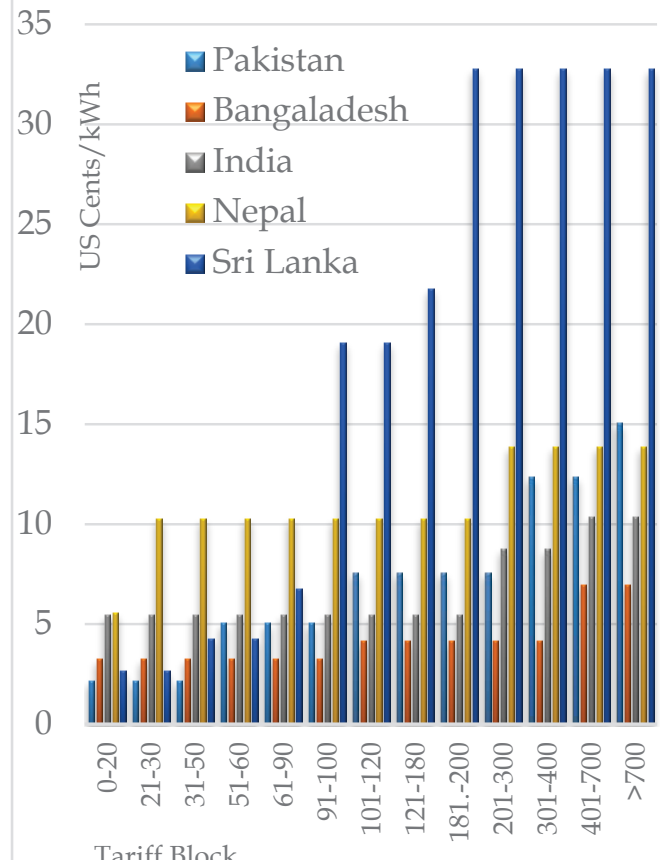

Figure 3 - Domestic electricity tariffs of few selected Asian countries [9].

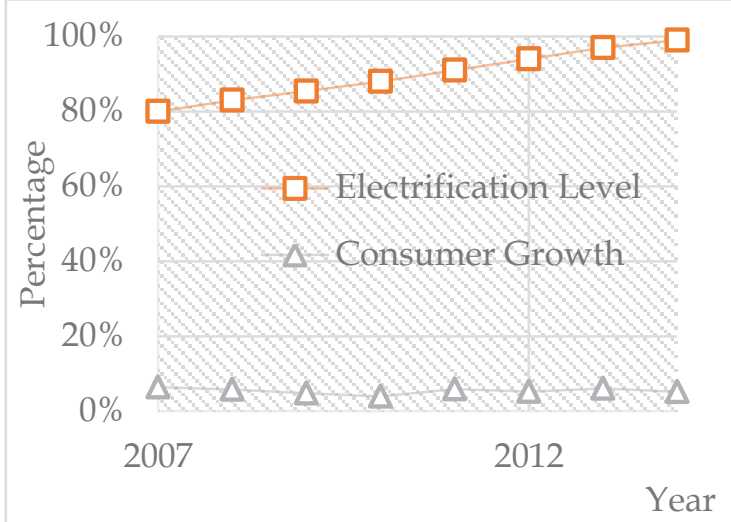

Figure 4 - Electrification level and consumer growth in Sri Lanka [5], [6].

\section{Methodology}

\section{Field Data Collection}

Kahawatta area in Sri Lanka was selected for the case study considering its electrification level, population and other socio economic factors.

The total population of the Kahawatta area consisting of 12,764 families is 45,330 . The electrification level of the area in 2013 was around $93.2 \%$. In 2010, the average monthly income per household had been 36,173 rupees with a monthly per capita income of 9,132 rupees [4]. 
The sample size selected for the study was 648 for the population of 12,764 so as to maintain a confidence level of $95 \%$ at a confidence interval of 3.75. Data collection was through questionnaires and interviews. One to one interviews were held with family representatives of the households selected, who were mostly the heads of the households concerned.

The survey was conducted for the random sample during a four weeks period. Information was obtained through direct interviews. Electrical equipment usage and its duration, tariff block type and financial data were obtained and recorded during the survey. The main concerns were the usage of energy inefficient equipment, quantification of the system peak electricity consumption by energy inefficient equipment and the savings expected through the introduction of energy efficient equipment. An analysis was carried out to find out the possibility of energy and electricity demand savings by equipping all subsidized houses with energy efficient equipment.

Electricity subsidies have been provided for obtaining electricity connections as well. The case study was focused on examining the distribution line enhancement Rural Electrification (RE) projects in the Ratnapura district.

Statistical details were taken from the CEB Sabaragamuwa Provincial Office and the Lighting Ratnapura Distribution Development Project. A survey was conducted among newly constructed RE schemes that were randomly selected. The target was to analyse the impact of the subsidy on the electricity connections in rural villages.

There were 201 RE schemes that had been implemented by end of 2014. A random sample of 155 was selected for the case study to comply with a confident interval of 3.75 and a confident level of $95 \%$.

\section{Results and Analysis}

\subsection{Intentions of Providing Electricity Subsidies}

In the past, the electricity subsidy has been one of the main issues addressed by both the government and the opposition parties in Sri Lanka during their election campaigns. There are many examples available to show that the electricity subsidy is highly politically biased and that it is focused on to gain short term political benefits despite being a heavy burden on the country.

During the survey, 78\% said that they will not be influenced by the electricity subsidy when they vote at the elections. Often electricity tariff revisions have been heavily influenced by political agendas. Normally, electricity prices are not based on the actual cost of electricity generation.

The fundamental intention of an electricity subsidy should be to give relief to low income electricity consumers. The government assumes that lower income families consume less electricity. Hence the subsidy is given based on the consumption. The lowest 30 unit block receives the largest subsidy. The amount of subsidy gradually reduces in 30 unit steps to stop at 120 units.

The government of a country should not consider the electricity sector on a standalone basis since the cost of lost generation will be much more than the cost of electricity lost in the country.

\subsection{Assessment of the Positive Impacts of Electricity Subsidies}

The intention of an electricity subsidy is to achieve positive outcomes for the society. Seventy-five percent of the domestic consumers in Sri Lanka enjoy the electricity subsidy [5]. Many positive impacts of the electricity subsidy identified during the case study are presented below.

Electricity was considered a luxury at the time of its introduction to the country. Until the time when the government introduced Rural Electrification (RE) Projects, only a very few urban people who were rich had the opportunity of enjoying electricity. The total expenses related to a service connection were charged from the prospective consumer. The payment for the service connection was unaffordable to rural people.

Furthermore, government's energy policy gives priority for improving the access to commercial energy such as electricity in rural areas. It also recognizes the need to provide subsidies to deserving groups in order to ensure that such groups can meet their basic energy needs at affordable prices. 
There are general policy guidelines set out specifically on the electricity industry by the Public Utilities Commission of Sri Lanka (PUCSL). These policy guidelines give high priority to rural electrification and the PUCSL is expected to recognize electricity as an essential requirement for rapid economic growth [21]. Accordingly, policies have been revised to make electricity available at state expense to every household which is within a maximum distance of $50 \mathrm{~m}$ from the national grid. The government gives a soft loan for the basic charges for providing a service connection which will be recovered through the electricity bill in the long term. Ultimately, every person in the country, especially the low income category, will get the opportunity to enjoy electricity.

There are three rapid hikes in the electricity bill when the consumption exceeds 60, 90 and 120 units. Households may feel the impact of this rapid change. Even a single unit increase in consumption will result in a large increase in the electricity bill. The increase of the bill for a single unit increase from 60 units is 291.00 rupees and from 90 units, it is 418.00 rupees (Figure 5). What is worst about this is that $87 \%$ of the people who took part in the survey were not aware of this fact.

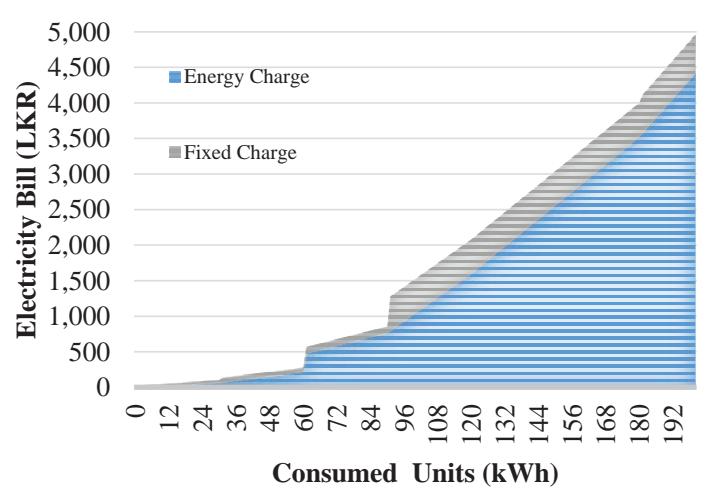

Figure 5 - Block tariff and the electricity bill

Because of these sudden increases, the people tend to go for energy efficient equipment. It was seen that consumers on the $90^{\text {th }}$ border have not used a single incandescent lamp for lighting. The investment made on CFL or LED lamps may be less than the increase in the electricity bill. However, consumers on the $60^{\text {th }}$ border were still not keen on saving electricity.

During the survey, it was identified that consumers on the borders are highly concerned on cutting down their electricity consumption at least by a few units. Some consumers said that they save electricity by completely shutting down their refrigerators during the last couple of days of the billing cycle. Some said that they refrain from using electric motor pumps to save electricity. From the point of view of conservation of electricity, it is a positive trend, although it is at the cost of lowering the quality of life.

Furthermore, some said that if they could not manage within the limit, they would try to negotiate with the meter reader to transfer one or two units to the bill of the following month. Thus, it is causing a negative impact on the revenue collection of the electricity utility by encouraging the consumers to resort to illegal acts.

The government of Sri Lanka has formulated many policies for the rapid and effective implementation of Rural Electrification (RE) projects. Funds for RE schemes are provided by the government as well as by international and national development banks.

The number of RE schemes has gradually increased from year 2006 to 2012 [14]. With government's target to meet $100 \%$ electrification, the CEB intensified and expedited the implementation of these projects. In addition, several system augmentation and rehabilitation projects were also implemented to improve the distribution network and thereby reduce the system loss. The RE projects have two categories, i.e., extension of the existing low voltage feeders which are called "Extensions" and the construction of new $33 \mathrm{kV}$ distribution lines, substations and low voltage feeders which are called "Schemes".

From the outcome of the case study, it has been identified that $2.5 \%$ of the beneficiaries have taken the advantage of having electricity to improve their income sources. Groceries, tailor shops, sweet manufacturing factories, cycle winkles and saloons are the places which use electricity and promote entrepreneurship in villages. The remaining $97.5 \%$ used electricity only for their day to day domestic consumption.

Electricity tariff for the industrial sector in Sri Lanka is fair when compared with those of the other South Asian countries. There is no question that the investments on the industrial sector in Sri Lanka as well as the job 
opportunities available in that sector have increased due to the low industrial tariff rates in force. This could be identified as a positive impact of the current tariff structure.

Indirect job opportunities have also been created when implementing RE projects. Most of those projects have been undertaken by private contractors in the localities of the projects. Local people get the opportunity to work under these contractors thereby earning additional income.

\subsection{Assessment of the Negative Impacts of Electricity Subsidies}

Subsidies cannot always be perfect as the intentions imply. Many short comings could be expected in practical operations. The following negative impacts can be found in the electricity subsidy implemented in Sri Lanka.

The intention of electricity subsidy was to give relief to low income people. Filtering low income people is both difficult and complex. Hence the subsidy was implemented on the assumption that low income people consume less electricity. From sample studies it has been identified that there is no direct relationship between the income and the electricity consumption.

In 2013, the number of "Samurdhi" holders was $1,477,313$ and the total number of electricity subsidy recipients was around $3,212,238$. Thus in that year, $1,734,925$ "NonSamurdhi" holders have received the electricity subsidy. Some also used to have multiple service connections for the different levels of their houses. In such cases, the subsidy is being provided several times for the same consumer. The present subsidy scheme fails to identify such malpractices specially those done by well to do consumers.

The monthly average electricity bill of non Samurdhi holders who received the electricity subsidy along with the actual cost of electricity generation for them were hypothetically calculated for the year 2013 . This calculation was based on the assumption that any given household will consume an average consumption for a particular tariff block (Table 2). Accordingly, it can be seen that the government bears a burden of around nine hundred million rupees per month to provide electricity subsidy to non-Samurdhi holders. It works out to about 10.7 billion rupees annually.
Table 2 - Monthly subsidy provided for nonSamurdhi holders

\begin{tabular}{|c|c|c|c|c|}
\hline 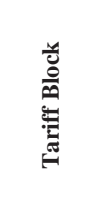 & 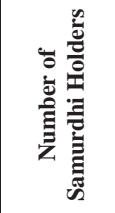 & 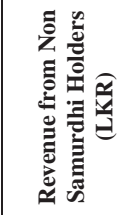 & 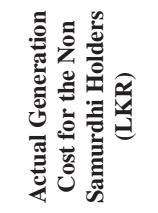 & 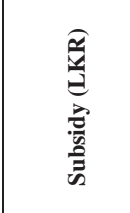 \\
\hline $\begin{array}{l}30<= \\
\text { Units }\end{array}$ & 442,018 & $34,477,385$ & $148,650,571$ & $114,173,186$ \\
\hline $\begin{array}{l}30< \\
\text { Units } \\
<=60\end{array}$ & 678,892 & $141,209,482$ & $540,737,272$ & $399,527,790$ \\
\hline $\begin{array}{l}60< \\
\text { Units } \\
<=90\end{array}$ & 614,016 & $436,565,022$ & $815,105,580$ & $378,540,557$ \\
\hline Total & $1,734,925$ & $612,251,890$ & $1,504,493,423$ & $892,241,534$ \\
\hline
\end{tabular}

It has been identified that consumers living close to one another are used to share electricity consumption although it is illegal. It happens when houses of consumers using low amounts of electricity are located close to the houses of consumers using large amounts of electricity. It was also identified that often those consumers are related to one another. Direct illegal tapings were not recorded during the survey. It is the general view that this kind of illegal tapings is common in certain areas but however in the area selected for the survey such practices were not common.

When a service is received at a low cost that is subsidized, careless consumption and wastage are inevitable. For example, the usage of low efficient electrical equipment such as incandescent lamps is common among the subsidized groups. Replacing an incandescent lamp by an energy efficient lamp will save energy by $80 \%$. It could benefit the utility in two ways, i.e., through the reduction in demand especially during the peak demand period and through the reduction in energy consumption. Both these values were calculated and the results of the entire 648 random sample were summarized under the respective tariff blocks.

Furthermore, expected saving in demand per consumer and saving in energy per consumer during peak times in the night were calculated under each tariff block. It was found that on average, a demand saving of $106 \mathrm{~W}$ and a daily energy saving of $0.47 \mathrm{kWh}$ per consumer would be possible by introducing energy efficient lighting equipment. 
Table 3 - Estimated daily energy savings through the introduction of energy efficient lighting

\begin{tabular}{|c|c|c|c|}
\hline Block & $\begin{array}{l}\text { Number of } \\
\text { Consumers } \\
\text { in the } \\
\text { population }\end{array}$ & \begin{tabular}{|c|}
$\begin{array}{c}\text { Possible } \\
\text { energy } \\
\text { saving per } \\
\text { consumer } \\
(\mathrm{kWh})\end{array}$ \\
\end{tabular} & $\begin{array}{c}\text { Possible } \\
\text { Energy } \\
\text { Saving } \\
\text { (MWh) }\end{array}$ \\
\hline $30<=$ Units & 818,374 & 0.43 & 351.90 \\
\hline $\begin{array}{l}30<\text { Units } \\
<=60\end{array}$ & $1,257,004$ & 0.53 & 666.21 \\
\hline $\begin{array}{l}60<\text { Units } \\
<=90\end{array}$ & $1,136,860$ & 0.58 & 659.38 \\
\hline $\begin{array}{l}90<\text { Units } \\
<=120\end{array}$ & 512,048 & 0.31 & 158.73 \\
\hline $\begin{array}{l}120<\text { Units } \\
<=150\end{array}$ & 217,271 & 0.17 & 36.94 \\
\hline $\begin{array}{l}150<\text { Units } \\
<=180\end{array}$ & 98,819 & 0.12 & 11.86 \\
\hline Units $<180$ & 75,365 & $\mathrm{~N} / \mathrm{A}$ & N/A \\
\hline \multicolumn{3}{|c|}{ Total } & $1,885.02$ \\
\hline
\end{tabular}

Island-wide consumer distribution under each tariff block which is based on survey results and the expected savings for the entire country are shown in Table 3. The total savings amount to $6 \%$ of the daily energy consumption in the country.

From the verbal interviews carried out during the survey, it was found that incandescent lamps were the most common energy inefficient equipment identified among the heavily subsidized group. The four reasons identified for the use of incandescent lamps especially among consumers in the low tariff blocks are as follows:
a. Un-affordability of cost of CFLs and LEDs.
b. Lack of knowledge about the energy consumption of different devices.
c. Low subsidized electricity tariff.
d. Non-availability of CFLs and LEDs in remote local markets.

Thus it would be prudent to device suitable policies and instruments to popularize as well as to enforce the requirement for replacement of incandescent lamps with energy efficient lamps.

The actual generation cost is not charged from consumers in the subsidized lower blocks. Although high end consumers are heavily charged, the revenue so obtained is not sufficient to cover the difference since more than $75 \%$ are subsidized consumers. The difference between the actual generation cost and the revenue collected for electricity is absorbed by the treasury.

\section{Conclusions}

Although the electricity tariff has been subsidized, there are still several unsolved problems in the electricity sector. The number of indirect negative impacts daunts the expected outcomes of the electricity subsidy.

Instead of providing general electricity subsidies on the basis of consumption, smarter methods which could address the intention of the subsidies properly need to be introduced.

This research proposes to provide the electricity subsidy only to needy people. The best category for the entitlement of the electricity subsidy will be the "Samurdhi" recipients who consume less than $120 \mathrm{kWh}$ per month. It could be offered in two categories based on the monthly income of a family unit. The same income limit of "Samurdhi Programme" could be adopted for the electricity subsidy too.

It is found that energy inefficient equipment is being heavily used by subsidized consumers. The main reason is their cheap initial cost. This equipment is freely available in rural areas where low end consumers are abundant. It is proposed to introduce a special tax to increase the prices of energy inefficient equipment so that the import as well as the production of such equipment will be discouraged.

Sri Lanka imports $40 \%$ of CFL and fluorescent lamps used in the country and $90 \%$ of HID lamps [16]. One-hundred percent of the LED lights are imported. Several tax rebates, such as import duty reduction and value added tax reduction on the sale of energy efficient equipment can be considered for encouraging the use of energy efficient equipment.

Although several initiatives are already underway, many countries still do not have any outright ban on the use of incandescent lamps. The main reasons for not taking such action are the affordability, quality and availability of these lamps. 


\section{References}

1. Anonymous, "Fuel, light bills plummet", Daily News Online, September 17, 2014.

2. Bandara, J. M. R. S., "Agriculture development towards nutritional security", Sunday Observer, October 11, 2009.

3. Central Bank of Sri Lanka, "Sri Lanka SocioEconomic Data, Vol. XXXVI”, June, 2013.

4. Central Bank of Sri Lanka, "Sri Lanka SocioEconomic Data, Vol. XXXVII", June, 2014.

5. Ceylon Electricity Board, "Annual Report 2011".

6. Ceylon Electricity Board, "Annual Report 2012".

7. Ekanayake, H. K. J., "Impact of fertilizer subsidy in paddy cultivation in Sri Lanka", Anonymous Publication, 2006.

8. Global Energy Statistics, "Enerdata",Web Publication,2012.

9. Jamil, F., “Comparison of Electricity Supply and Tariff Rates in South Asian Countries", Anonymous Publication, 2011.

10. Jayasundera, P.B., "We manage our economy without touching subsidies given to public",Web Publication,2012.

11. Ministry of Finance and Planning, "Poverty Indicators", Household income and expenditure survey 2009/10, May, 2011.

12. Ministry of Finance and Planning, "Annual Report", 2012.

13. Navaratne, T.L., "Political Economy of Access to Energy by the Rural Sector in Sri Lanka with specific reference to Rural Electrification", The Political Economy of Energy and Natural Resource Use, 2013.

14. Siriwardana, A., "Fuel price reduction an election gimmick: UNP". Daily Mirror, September 19, 2014.

15. United Nations Environment Programme, "Energy Subsidies: Lessons Learned in Assessing their Impact and Designing Policy Reforms", UNEP Publication, 2001.

16. The World Bank, WashingtonD.C, "South Asia Development Matters",2011. 